\title{
Maribel Fierro/Mayte Penelas The Maghrib in the Mashriq. Knowledge, Travel and Identity. Introduction
}

I am the sun shining in the sky of knowledge But my fault is to have risen in the West.

Had I risen in the East, Great would be the plunder of my lost renown. -Ibn Ḥazm (d. 456 H/1064 CE) ${ }^{1}$

Are you not unjust in judging us, oh, people of the East? ... Why do they not admire what is good and stop despising what is of value? ... We recite what one of our poets said:

"Your merits make us rejoice, Why do you refuse to accept ours?

Do not envy us if some stars

Shine in our firmament; And, if you have more outstanding feats to be proud of, Do not treat with injustice the few we have". -Ibn Dihyya (d. 633 H/1235 CE)

Ha, thou hast had thy day, Proud jewel of Cathay! My ruby I acclaim, My Andalusian flame. -Ibn $\mathrm{Hazm}^{3}$

1 Ibn Bassām, al-Dhakhīra (1978-81), 1/1: 173-174; al-Maqqarī, Nafṭ al-țīb (1968), 2: 81. English translation by Camilla Adang.

2 Ibn Dihya, al-Muțrib (1429/2008), 128. Our English translation is based on the Spanish translation by Gazi 1953, 180-181, http://institutoegipcio.es/wp-content/uploads/2018/09/Vol.-I-Revista-del-Instituto-Egipcio-de-Estudios-Isl\%C3\%A1micos-1952-1.pdf. We thank Teresa Garulo for her help.

3 Ibn Ḥazm, Ṭawq al-ḥamāma (1978), 182; English translation by Arberry, http://www.muslimphilosophy.com/hazm/dove/chp19.html (accessed Jan. 21, 2020).

Note: This contribution has been written within the project Local contexts and global dynamics: al-Andalus and the Maghreb in the Islamic East (FFI2016-78878-R AEI/FEDER, UE), co-directed by Maribel Fierro and Mayte Penelas with funding from the Spanish Ministry of Science, Innovation and Universities. English revision by Nicholas Callaway. 
In his 1970 book The History of the Maghrib, Moroccan historian Abdallah Laroui pointed to the need "to trace the genesis of the concept of the Maghrib and to discover how it took on an objective definition". ${ }^{4}$ The Maghrib - the 'West' in Arabic - inevitably refers to its pair, the Mashriq - the 'East' - and is often used in a binary spatial opposition assumed to convey an inherent meaning on its own. However, this meaning must nevertheless be contextualized in time, while recognizing that each element, East and West, likewise involves internal boundaries and other possible oppositions. For example, does al-Maghrib include al-Andalus? Can it include Egypt? When do Arabic sources use the term al-Maghrib to refer to the lands that today correspond to parts of Libya, Algeria, Tunisia and Morocco, and why? Moreover, binary oppositions always run the risk of distorting the realities on the ground, which inevitably involve shifting boundaries, crosscurrents and interactions. ${ }^{5}$ If space and time are basic elements to be discussed when using the terms Maghrib and Mashriq, the latter also convey certain hierarchical assumptions about a cultural, intellectual and religious centre and a periphery, as reflected in the poems quoted above. ${ }^{6}$ These assumptions, again, need to be fleshed out in all their details and temporal variations, and should be opened up to discussion and rethinking. The study of knowledge exchange and scholarly mobility across regions in the same cultural and/or religious domain often reveals that binary oppositions between innovative centres and imitative peripheries obscure flows of exchange that go both ways, not just from the centres to the peripheries, but also in reverse, and at times using channels that directly connect periphery to periphery, bypassing the centre altogether. ${ }^{7}$ One example among many is the one that follows below.

The Kufan traditionist Abū Bakr Ibn Abī Shayba (159-235 H/775-849 CE) compiled many traditions, Prophetic and otherwise, in his Mușannaf. ${ }^{8}$ The Cordoban Baqī b. Makhlad (201-276 H/817-889 CE) studied this work with its author during his stay in the East on his journey in search of knowledge, at a time when hadith and its science ('ilm al-hadith) were reluctantly being introduced in al-Andalus. There is a record of the transmission in al-Andalus of Baqi b. Makhlad's

4 Laroui 1977, 8. For the context in which he wrote see Jebari 2015, https://www.academia.edu/30848750/The_production_of_critical_thought_in_the_Maghrib_Abdallah_Laroui_and_Hichem_Dja\%C3\%AFt_1965-1978 (accessed Jan. 9, 2020).

5 See for example the introduction in Hamdani 2014.

6 For an illuminating case of the enduring conception of the Maghrib as an intellectual periphery in the Islamic world see Saleh 2011. Cf. for the case of al-Andalus in a European context, Curta 2011.

7 Melchert 2012.

8 Pellat, "Ibn Abī Shayba”, $E I^{2}$. 
recension (riwāya) of Ibn Abī Shayba's Muṣannaf over almost three centuries. Indeed, the text seems to have been central in the training of scholars who were interested in the study of hadith and were critical of traditional Mālikism. ${ }^{9}$ Why Ibn Abì Shayba's Mușannaf disappeared starting in the mid-6th/12th century from the lists of works transmitted, as reflected in the Andalusi fahäris genre, remains a topic for future research, ${ }^{10}$ but it can most probably be interpreted as a reaction against the Almohad policies that aimed at substituting Mālikism with a return to the original sources of Revelation. Baqi b. Makhlad's recension of the Musannaf is of great interest for the study of the local transmission and production of hadith-related knowledge, but it also transcends the local context. As such, it has been described as an "Andalusian" book that records a Kufan perspective". ${ }^{12}$ Two manuscripts of the work are preserved in Turkish libraries (Süleymaniye and Topkapi), another indication of the strong presence that knowledge produced in the Western regions of the Islamic world enjoyed in Ottoman centres of learning. ${ }^{13}$ Another manuscript is located still further East, in the Royal Asiatic Society of Bengal, and it was precisely in India that Ibn Abi Shayba's Muṣannaf was first printed, by 'Abd al-Khāliq Khān al-Afghānī. While the figure of the Iraqi Ibn Abī Shayba is of interest for the many scholars of different academic and national backgrounds whose research deals with early Islamic

\footnotetext{
9 It was mostly transmitted via a Sevillian family, the Banū al-Bājī al-Lakhmī. The last member recorded as a transmitter is Abū Marwān 'Abd al-Malik b. 'Abd al-'Azīz b. 'Abd al-Malik ... b. Sharīa (d. 532 H/1138 CE). Famous Andalusi traditionists such as Ibn Ḥazm (d. 456 H/1064 CE), Abū 'Umar Ibn 'Abd al-Barr (d. 463 H/1071 CE) and Abū Muhammad Ibn 'Attāb (d. 520 H/1126 CE) also transmitted Ibn Abī Shayba's work. The riwāya by al-Wakī'ī (3rd/9th century), another of Ibn Abī Shayba's students, also circulated in al-Andalus. This information has been taken from the Historia de los Autores y Transmisores de al-Andalus (HATA), directed by Maribel Fierro, available online at http://kohepocu.cchs.csic.es/.

10 At around the same time (first half of the 6th/12th century), another early work, a compilation of legal questions by the Cordoban al-'Utbī (d. $255 \mathrm{H} / 869 \mathrm{CE}$ ), also seems to have stopped being transmitted. In this case, the fact that Ibn Rushd al-Jadd (d. 520 H/1126 CE) had incorporated its text into his commentary, which explained and updated the contents of al-'Utbì's work, made its independent transmission redundant. See Fernández Félix 2003.

11 Since the term "Andalusian" also refers to modern Andalucía, it can lead to confusion when used in reference to the Arab past. For this reason, throughout this collective volume we have used the term "Andalusi" in reference to al-Andalus, except in quotations from other authors.

12 Lucas 2008, 287.

13 While imperial dynamics were clearly at work in this process, this Andalusi presence is a topic that deserves to be studied in its specifics. The presence of mystical works such as those by Ibn Barrajān can be linked to the impact of Muhyī al-Dīn Ibn 'Arabī. See Küçük 2013a; Küçük 2013b. For other fields see for example İhsanoğlu 2015; El-Rouayheb 2015; Vázquez Hernández 2018; Riedel (in press).
} 
matters in the central lands of Islam, the figure of the Andalusi Baqī b. Makhlad has mainly elicited the interest of Spanish and Moroccan scholars. ${ }^{14}$ While this is perhaps to be expected, the interest expressed by Pakistani and Indonesian scholars is less self-evident. ${ }^{15}$

Are scholars from regions considered peripheral from an Arab point of view bound to find interest today in what happened in other regions that in the past

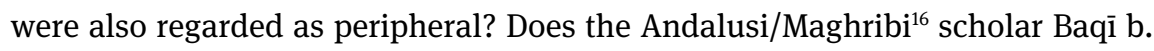
Makhlad's decisive role in the preservation of a seminal early Mashriqi hadith work make him, too, a central figure? How does one establish when (and if) peripheries and peripheral figures cease to be considered as such? How are we to categorize scholars whose travels and engagement in knowledge networks saw them overcome barriers of space and time? Can we isolate the study of figures of the past from their representation in the present? ${ }^{17}$ These and other questions are addressed in this collective volume that aims to explore how travel, knowledge and identity intersected in the circulation and impact of Andalusi/Maghribi scholars and their works in the Mashriq.

In December 2016, the Spanish Ministry of Science, Innovation and Universities granted funding for a research project under our direction entitled Local contexts and global dynamics: al-Andalus and the Maghreb in the Islamic East, to be carried out over four years. ${ }^{18}$ Drawing inspiration from Richard W. Bulliet's call to

14 Marín 1980; Ávila 1985; Mu'ammar 1988; Mu'ammar 1996.

15 Raisuddin 1988; Raisuddin 1993. Muhammad Akmaluddin wrote his MA Thesis on Silsilah Riwāyah al-Aḥādìth fì al-Andalus: Dirāsah Jīniyālūjiyyah li Tațawwur Riwāyah al-Aḥādìth fi alQarn al-Thānī wa al-Thālith al-Hijrī, at the Tafsir and Hadith Department, Faculty of Theology and Humanities, State Islamic University (UIN) Walisongo, Semarang Central Java, 2015. See also Akmaluddin 2017.

16 As explained by Luis Molina in "The Integration of al-Andalus in Islamic Historiography. The View from the Maghrib and the Mashriq” (Molina 2020), and by Giovanna Calasso in the paper here included, while a difference is made between al-Andalus and the Maghrib by some authors and in certain periods, al-Andalus was also at times considered to be part of the Maghrib. We use Andalusi/Maghribi to reflect this convergence when appropriate: Baqī b. Makhlad was an Andalusi scholar, but for Moroccans today - who consider themselves the inheritors of the legacy of al-Andalus - he is a Maghribi scholar. For a general background of the subject see Calderwood 2018.

17 See respectively for the last two questions al-Musawi 2015 and El Shamsy 2020.

18 Contextos locales y dinámicas globales: al-Andalus y el Magreb en el Oriente islámico (AMOI), FFI2016-78878-R AEI/FEDER, UE. The other members of the project are: Camilla Adang (Professor of Islamic Studies at Tel Aviv University), José Bellver (post-doctoral researcher at the Université Catholique de Louvain), Víctor de Castro (post-doctoral researcher at the Max Planck Institute for the History of Science), Teresa Garulo (Professor of Arabic and Islamic Studies at Complutense University), Aurora González Artigao (pre-doctoral researcher at the Institute of 
look at the Islamic world from the edge, ${ }^{19}$ as directors of the project our main interest in this first stage has been threefold: to map what has been written on the topic in general with the aim of producing an annotated bibliography available online; to concentrate on the study of the impact that knowledge produced in alAndalus/the Maghrib had in the fields of historiography, law and the religious sciences, poetry and literature, and mysticism; and to explore the possibilities that the digital humanities have to offer for our study. What we are presenting here is the result of the first international conference we convened, held on 2021 December 2018 at the Residencia de Estudiantes in Madrid. ${ }^{20}$ Not all the papers presented there have been included, ${ }^{21}$ and we have also added some new papers that were not presented at the original conference. In this process our collaboration with our colleagues in Japan has proven especially fruitful; we are particularly thankful to Professor Kentaro Sato, who organized a panel at the Sixth Conference of the School of Mamluk Studies (Waseda University, Tokyo, 15-17 June 2019) on Intellectual activities across the regions in the Mamluk period: Views from al-Andalus and Khurasan, which included Maribel Fierro's contribution to this volume. We are also very grateful to Professor Giovanna Calasso for contributing to the volume with her study on how the Maghrib was represented in medieval Arabic sources, an important step forward along the path indicated by Abdallah Laroui.

In what follows, we will trace, through the different contributions included in this volume, the main threads that guided us during the conference in Madrid. Parts I and II examine how knowledge produced about the Maghrib was integrated in the Mashriq, starting with the emergence and construction of the concept 'Maghrib'. Parts III and IV discuss how travel not only enabled knowledge produced in the Mashriq to be received in the Maghrib, but also allowed locally produced knowledge to be transmitted outside the confines of the Maghrib, in addition to the different ways in which this transmission took place. In Part V, we will see how the Maghribis who stayed or settled in the Mashriq manifested their

Languages and Cultures of the Mediterranean, CSIC), Abdenour Padillo (pre-doctoral researcher at the School of Arabic Studies, CSIC, and the Institute of Languages and Cultures of the Mediterranean, CSIC), Maxim Romanov (Universitätsassistent für Digital Humanities, University of Vienna), and Iria Santás (lecturer at the Universidad Eclesiástica San Dámaso).

19 Bulliet 1994. Cf. Fierro 2018.

$20 \mathrm{http}: / /$ cchs.csic.es/en/event/conference-maghrib-mashriq.

21 Javier Albarrán's paper, "From the Islamic West to Cairo: Malikism, Ibn Tūmart, al-Ghazālī and al-Qāọī 'Iyāḍ’s death”, will appear in María Marcos Cobaleda, ed., Artistic and Cultural Dialogues in the Late Medieval Mediterranean. 
identity. Lastly, we will offer our thoughts on future avenues of research that still lie ahead.

\section{Part I: Establishing Boundaries between the Maghrib and the Mashriq}

In his autobiography, the emir of Granada 'Abd Allāh b. Buluggīn - a member of the Berber Zīid family - recounts the moment when the Almoravid emir, the Sanhāja Berber Yūsuf b. Tāshufinn, had to decide what policy to pursue regarding the Iberian Peninsula (al-Andalus). ${ }^{22}$ In this account, when asked about his intentions, Ibn Tāshufīn prefaced his answer by proudly stating, "I am a Maghribī". ${ }^{23}$ Indeed, the Maghrib and related terms acquired special saliency and became a token of pride following the establishment of the Berber empires, first with the Almoravids and especially under the Almohads (5th-7th/11th-13th centuries). ${ }^{24}$ However, this had not always been the case, as Giovanna Calasso demonstrates in the study that opens this collective volume.

Calasso provides us with a historical overview of the conceptualization of the terms maghrib and mashriq from early times up until the 7th/13th century, especially in geographical writings and travelogues, and paying attention to the semantic web formed by other terms through which Muslims made sense of the world they inhabited, both in its own right and in relation to other human groups. The expressions dār al-islām (abode of Islam) and dār al-ḥarb (abode of war $)^{25}$ that made their first appearance in legal treatises were rarely used by Eastern geographers active between the 3rd/9th century and the 4th/10th century, who favoured expressions such as bilād al-rūm (the lands of the Byzantines/Romans/Christians) and bilād/mamlakat al-islām (the lands/kingdom of Islam). They inserted in their works well-documented descriptions of the Western regions of the bilād al-islām, most especially Ifrīqiya (Tunisia), which paid allegiance to the 'Abbāsids. Al-Ya'qūbī (late 3rd/9th century) devoted limited space to the Maghrib, conceived as the westernmost part of the Islamic lands'

22 On the equivalence of the term "al-Andalus” with the Iberian Peninsula see García Sanjuán 2003.

23 'Abd Allāh b. Buluggīn al-Zīrī, al-Tibyān (1995), 167; 'Abd Allāh b. Buluggīn al-Zīrī, al-Tibyān (1986), 163.

24 Mehdi Ghouirgate has paid special attention to this issue in, for example, "Al-Lisān al-gararbi : la langue des Almohades" (in press).

25 Calasso/Lancioni 2017. 
"western rub", to which Syria and Egypt also belonged, and he did not include any comparison with the East. There is no indication of a frontier in his work either, nor of a hierarchy. By contrast, Ibn al-Faqīh (3rd/9th century) did include a hierarchical view, according to which the Maghrib corresponded to the "worst part" of the world - perhaps a reflection of the negative view left by the Berber rebellions that had caused much trouble to the Umayyads, and by the Andalusi bid for autonomy from the 'Abbāsids. Starting in the 2nd/8th century, political independence under the Cordoban Umayyads in fact gave al-Andalus an identity of its own that was constructed against the Mashriq, ${ }^{26}$ but only up to a point. It could not have been otherwise: after all, the Umayyads came from the Mashriq, where their ancestors had been caliphs, and their hatred of the 'Abbāsids did not stop them from imitating and emulating them. The East - especially Iraq - was much valued for its cultural achievements, so much so that the poet Ibn Shuhayd (382-426 H/992-1035 CE), at the time of the collapse of the Cordoban Umayyad caliphate, criticized the inhabitants of Córdoba for "Berberizing, Westernizing, and Egyptianizing” (tabarbarū wa-tagharrabū wa-tamașșarū). ${ }^{27}$ For some Andalusis, it was in fact the 'other shore' of the Strait of Gibraltar ( $a l^{-'} u d w a$ ), the land of the 'Berbers', that functioned as the main focus of alterity. ${ }^{28}$ Thus, the poetking of Seville al-Mu'tamid (d. 488 H/1095 CE), jailed at Aghmāt near Marrakesh by the Almoravid emir, referred to himself as a "stranger in the land of the 'Westerners"” (gharīb bi-ard al-maghribiyyīn). ${ }^{29}$

The distinction/opposition between Mashriq and Maghrib - the latter understood as Northern Africa west of Egypt - emerged in the works of the 4th/10thcentury geographers Ibn Hawqal and al-Muqaddasī. Behind it was the boundary between the Sunnī 'Abbāsid caliphate and the Ismā'îlī Fāṭimid caliphate, first established in Ifriquiya. This separation would again resurface in the 6th/12th century with the establishment in North Africa and al-Andalus of the Almohad caliphate, built against the Almoravids, who had paid allegiance to the 'Abbāsids. ${ }^{30}$ By the 5th/11th century, the Andalusi al-Bakrī (d. 487 H/1094 CE) held that alAndalus, as a frontier of the mamlakat al-islām with the Christian world, was an

26 Criticisms of the Mashriq can be documented since early times. See Fierro 2019. See also alMunajjid 1963; El Erian El Bassal 2013.

27 Ibn Shuhayd, Dīwān (1969), 110. The term tagharrub has its counterpart in the tasharruq used to define the Ismā'îlīs/Fātịmids in North Africa, a derogatory term through which they were dismissed as foreigners. See Ibn al-Haytham, al-Munāzarāt (2000), 22-23.

28 Rouighi 2010; Rouighi 2019.

29 Apud Ibn Bassām, al-Dhakhīra (1978-81), 3: 75; López Lázaro 2013, 273.

30 On how this period was viewed in the East see Ben El Hajj Soulami 2014. 
extension of the Maghrib. Once al-Andalus was incorporated into the Berber empires of the Almoravids and the Almohads, it became, in fact, an integral part of the Maghrib. Between the end of the 6th/12th century and the 7th/13th century, authors of travelogues and geographers from the Maghrib such as Ibn Jubayr (d. 614 H/1217 CE), al-'Abdarī (fl. ca. 688 H/1289 CE) and Ibn Sa'īd (d. 685 H/1286-7 CE) compared the East and the West of the Islamic world, emphasizing differences and offering criticism of the Mashriq, admired for its knowledge, but blamed for its deficiencies in the sphere of religion. This represents the emergence of a new reverse hierarchy, which had its precedents among the North African Ibādīs, who had been pioneers in praising the merits of the Berbers and consequently of the land they inhabited. ${ }^{31}$

In 6th/12th-7th/13th-century geographical works and travelogues, Egypt is usually represented as the gateway to the East. Ibn Sa'îd (d. 685 H/1286-7 CE), usually known in Eastern sources as Ibn Sa'īd al-Maghribī, left al-Andalus in $636 \mathrm{H} / 1238-9 \mathrm{CE}$ and lived the rest of his life abroad, mostly in Egypt. His scholarly interests included poetry, belles-lettres ( $a d a b$ ), history and geography. As shown by Víctor de Castro's contribution, Ibn Sa 'īd's Kitāb Basṭ al-arḍ fi al-țūl wal-'ard, also known as Kitāb Jughräfiyā, became a source for a number of Eastern authors such as Abū al-Fidā' (d. 732 H/1331 CE), Ibn Faḍl Allāh al-'Umarī (d. 749 H/1349 CE), al-Qalqashandī (d. 821 H/1418 CE), and al-Maqrīzì (d. 845 H/1442 CE). In it, Egypt appears sometimes as part of the West, sometimes as part of the East. The variations in Ibn Sa'îd's conceptualization of Egypt do not end here: in his compilation of poetry entitled al-Mughrib fi hulā al-Maghrib, the Maghrib is taken to encompass not only Ifrīqiya, the rest of the Maghrib, and al-Andalus, but also Egypt. While we find that in general the limits of the Maghrib may vary from one author to another, this is the only instance where they are taken to include Egypt. Ibn Sa 'îd's unusual choice in the Mughrib, moreover, was not followed by other members of his family: for his uncle 'Abd al-Raḥmān b. Muḥammad b. 'Abd al-Malik b. Sa'īd (d. 616 H/1220 CE), Ifrīqiya represented the door to the East. As one might expect, Ibn Sa'īd's 'Maghribization' of Egypt led to controversy, especially among Mamlūk authors in Egypt, with Ibn Faḍl Allāh al-'Umarī being the most forceful in his disagreement. He replied to Ibn Sa'îd by dedicating volume five of his Masālik al-abșār fi mamālik al-amșār to this issue. In it, al-'Umarī accuses Ibn Sa îd of partiality and favouritism towards the Maghribis. As for scholar Abū al-Fidā', his criticism was based mainly on issues related to latitudes and longitudes. The fact that for Easterners the West was often perceived as inferior

31 Felipe 2018; Aillet (forthcoming; we thank the author for allowing us to quote his unpublished article). 
meant that Ibn Sa 'îd's attempt at integrating Egypt into the Maghrib was doomed to be rejected by the Egyptians. The reasons that moved him to include Egypt are still unclear. The Maghrib and Egypt had been politically united under the Fātimids; was Ibn Sa'īd proposing a similar union under the rule of the Ḥafșids, who touted themselves as the rightful heirs to the Almohad caliphate? ${ }^{32}$

\section{Part II: Integrating the Maghrib into Universal Islamic History}

Luis Molina has studied how Eastern Muslim historians, after the period of the Islamic expansion, almost completely ignored the events taking place in the regions west of Egypt. ${ }^{33}$ Later Eastern interest in the Maghrib, especially evident in Ibn al-Athir (d. $630 \mathrm{H} / 1233 \mathrm{CE}$ ), chronologically coincides with the rise of the Almohad caliphate, and was highly dependent on historical sources written in alAndalus and the Maghrib that circulated in the East in close connection with the travels and emigration of Andalusi and Maghribi scholars. ${ }^{34}$ At the same time, some historical works were written in the East by Maghribi authors who had settled there, ${ }^{35}$ with the patronage of Șalāh al-Dīn b. Ayyūb (d. 589 H/1193 CE) - better known as Saladin - being hugely influential. ${ }^{36}$

In Abū al-Fidā's Mukhtașar fi akhbār al-bashar, a work that spans from the creation of the world up to the year $729 \mathrm{H} / 1329 \mathrm{CE}$, al-Andalus appears as an unstable region on the periphery of the Islamic world. Abdenour Padillo-Saoud analyses how the Syrian historian approaches al-Andalus in a work in which he summarizes the information found in his sources on the political events that took place in a given year. His main sources for al-Andalus were, unsurprisingly, Ibn

32 On the political dynamics between Ḥafșid Ifrīqiya and Egypt see Chapoutot-Remadi 1979.

33 Molina 2020.

34 The literature on this topic is abundant, a representative handful of references being: Pouzet 1975; Marín 1995; Baadj 2019.

35 As in the case of al-Yasa' b. Hazm (d. 575 H/1179 CE), author of the Kitāb al-Mughrib fi akhbār maḥāsin ahl al-Maghrib, which he wrote for Șalāḥ al-Dīn, and 'Abd al-Wāḥid al-Marrākushī (d. after $621 \mathrm{H} / 1224 \mathrm{CE}$ ), author of Kitāb al-Mu'jib fi talkhis akhbār al-Maghrib, which he wrote for a vizier of the 'Abbāsid caliph al-Nāṣir (d. 622 H/1225 CE). See respectively Fierro 1995 and Benhima 2009.

36 Not only in the field of history but also in others such as poetry. See Bray 2019a and Bray 2019b. 
al-Athīr's al-Kāmil fi al-tārīkh ${ }^{37}$ and Ibn Sa 'īd's Mughrib. Abū al-Fidā' includes records of around one hundred historical events that took place in al-Andalus, interspersed with other information whose only common trait is having occurred in the same year. Abū al-Fidā's account begins with the arrival of 'Abd al-Raḥmān I (d. $172 \mathrm{H} / 788 \mathrm{CE}$ ), whereas his main source, al-Kāmil fi al-tārīkh, offers an extensive account of the conquest of al-Andalus and its aftermath. Abū al-Fidā' largely skims over the Umayyad period, perhaps because he himself was a prince of the Ayyūbid dynasty whose founder, Șalāh al-Dīn, had recognized the pre-eminence of the 'Abbāsid caliphate. Abū al-Fidā' seems more interested in al-Manșūr b. Abī 'Āmir, or Almanzor (d. $392 \mathrm{H} / 1002 \mathrm{CE}$ ), the de facto ruler of al-Andalus towards the end of the Umayyad caliphate, whose military campaigns against the Christians gained him fame and with whom Abū al-Fidā' - who took part in multiple campaigns against the Crusaders - may have felt affinity. After dealing with the period of the collapse of the Umayyad caliphate (fitna) and the subsequent taifa kingdoms, when it comes time to cover the Almoravids and Almohads Abū alFidā' only focuses on events in North Africa and, likewise, shows no interest in the Nașrid Kingdom of Granada. ${ }^{38}$

Both Ibn al-Athīr and Abū al-Fidā' lived in Syria, a region where the memory of the Umayyad past was likely to arouse interest in al-Andalus, ${ }^{39}$ as was indeed the case later on when the Maghribi al-Maqqarī (d. 1041 H/1632 CE) was asked by a Syrian patron to write about the memory of a land that had by then been irremediably lost to the Christians. ${ }^{40}$ Such an interest is not to be expected in regions further east, but, as explained by Philip Bockholt in his contribution, even if they had wanted to, historians in 10th/16th-century Iran would have been hardpressed to find knowledge on far-off regions of the Islamic world like al-Andalus and the Maghrib. While works like the Tārìkhnāma written by Bal'amì under the Sāmānids in the 4th/10th century devote only a few lines to the history of the Islamic West, chronicles composed in İlkhānid-Mongol times (ca. 655-755 H/ 1257-1355 CE) contain more information, even including accounts of Christian Iberia. Nevertheless, Khvāndamīr (d. 942 H/1535-6 CE) did not have any information on hand about events taking place in the western parts of Islam from the 7th/13th century onwards, even though he belonged to a family of historians and had access to the libraries of Herat, at that time one of the main cultural centres in the eastern lands of Islam. However, Khvāndamīr's Habīb al-siyar fi akhbār

\footnotetext{
37 Al-Darwīsh 2015.

38 On this topic see Maḥmūd al-Bațūsh 2016.

39 Borrut/Cobb 2010.

40 Elger 2002; Moral 2014; Adil 2019.
} 
afrād al-bashar does include materials about the early times of Islam in the Iberian Peninsula, and also covers the history of the Berber Muslim dynasties of the Almoravids and Almohads (ca. 455-668 H/1063-1269 CE) at length. Among the Almohad rulers, Abū Yūsuf Ya'qūb (d. 595 H/1199 CE) is given special attention. Khvāndamīr first presents his life, before going on to provide an account of the 591 H/1195 CE battle of Alarcos, in which the Almohad caliph defeated the Christians. However, Khvāndamīr mistakenly refers to it as the "the battle of al-Zallāqa”, another victorious Muslim campaign against the Christians that had taken place in the year $479 \mathrm{H} / 1086 \mathrm{CE}$ under the rule of the Almoravid emir Yūsuf b. Tāshufīn (d. 500 H/1106 CE). Khvāndamīr's only source for the chapters dealing with the Almohad dynasty, and hence for the battle of Alarcos, was Mir'ät aljanān by the Yemenite scholar al-Yāfi ' 1 (d. 768 H/1367 CE). The latter mainly copied the information given in Abū Shāma's (d. 665 H/1267 CE) Dhayl al-Rawḍatayn and in Ibn Khallikān's (d. 681 H/1282 CE) Wafayāt al-a yān. Among the sources for Ibn Khallikān's account were members of the Maghribi community in Damascus, including the famous mystic Muhyī al-Dīn Ibn al-'Arabì, who died in Damascus in 638 H/1240 CE. Ibn al-Athīr's Kämil contains a similar, though not identical, strand of Arabic historiography about the battle of Alarcos. Later authors based their narratives on al-Kāmil, as well as on Abū Shāma and Ibn Khallikān. It was via their books that authors in Iran had access to knowledge about events in the West.

If the political history of the Maghrib was of interest to historians writing especially for a readership at the ruler's court, the lives of scholars and men of letters from the western regions of Islam were more likely to prove relevant for other scholars and men of letters living elsewhere. ${ }^{41}$ This was bound to happen when Andalusi and Maghribi scholars settled in the East and became part of the local intellectual and religious landscape. ${ }^{42}$ But what about those who never left their homeland, or returned to it after having travelled to the East? Qāḍi 'Iyāḍ (476-

41 Both types of information were combined by al-Dhahabì (d. $748 \mathrm{H} / 1348 \mathrm{CE}$ ) in his massive work Tārīkh al-islām. Maxim Romanov has used the tabaqāt included in this work to study, among other topics, the interregional connections between Iberia and the Levant from 1100 to 1600, using digital humanities tools. See Romanov 2017, esp. 241-243, figures 10-13. The Estudios Onomástico-Biográficos de al-Andalus series, published by the CSIC in Madrid and Granada (with 18 volumes to date, since 1988), includes a number of studies on biographies of Andalusis found in Eastern biographical dictionaries, information that may now be studied from a digital humanities approach.

42 A case in point is that of the Jewish man of letters Yehūda al-Harīzī, who left the Iberian Peninsula and settled in Ayyūbid Aleppo, where he lived until his death, and whose biography was recorded in Eastern Arabic sources. See Sadan 2002. 
$544 \mathrm{H} / 1083-1149 \mathrm{CE})$, a scholar from Ceuta whose travels for study never took him outside the region, is among the Maghribi scholars who have elicited the most sustained attention across the Islamic world through the centuries. ${ }^{43}$ This mostly has to do with the huge success of his al-Shifā' bi-ta'rîf ḥuqūq al-Musțafā - a work on the prerogatives and merits of the Prophet Muhammad - among Muslims both past and present. ${ }^{44}$ Even during his own lifetime, entries on Qāḍī 'Iyāḍ̂'s life and intellectual production were already included in a number of biographical dictionaries not only in the Maghrib, but also in the Mashriq. In her contribution, Maiko Noguchi carries out a detailed comparison of the descriptions of Qādī 'Iyāḍ in these biographies. Through her analysis, she reveals how certain elements are given more or less emphasis, and how the differences in the resulting portrayals are related to the biographers' various contexts. Her study contributes to our understanding of how intellectual networks are created that transcend direct physical connections. If students of Qāḍi 'Iyāọ, and students of his students, were decisive in making him and his work known outside the Maghrib, the inclusion of entries on Qāọi 'Iyāọ in Eastern biographical dictionaries gave him - in connection with the circulation of his work - a 'life of his own'.

\section{Part III: Maghribi Success in the East}

Having risen to power in the far-western and central Maghrib toward the end of Qāḍī 'Iyāọ’s life, the Almohads sought to re-centre the Islamic world around the figure of their Mahdī, the Berber Ibn Tūmart (d. 524 H/1130 CE). Characterizing him as an impeccable imām and inheritor of the station of prophecy (wärith maqām al-nubuwwa), ${ }^{45}$ his successor 'Abd al-Mu'min (d. $558 \mathrm{H} / 1163 \mathrm{CE}$ ) promoted the view that the centre of Islam had shifted from the Mashriq to the Maghrib, touted as the new Hejaz, with a sanctuary in Tinmal in the Atlas mountains where the Mahdī and his successors, the Mu'minid caliphs, were buried. This shift inevitably bolstered Maghribi identity and pride, and lent new significance to an oft-

43 There is a famous saying that states: "If it were not for Qāḍi 'Iyāạ, the Maghrib would not have been known”. See, e.g., al-Ifrānī 2000, 33; Ibn Tāwīt 1402/1982, 59.

44 Dagmar Riedel studied the spread of this work as a Marie-Curie fellow at the Institute of Languages and Cultures of the Mediterranean, CSIC (2017-2019), with a project entitled Making Books Talk: The Material Evidence of Manuscripts of the Kitāb al-Shifā' by Qādī 'Iyād (d. 1149) for the Reception of an Andalusian Biography of the Prophet between 1100 and 1900.

45 Fierro 2016, 83. 
cited Prophetic tradition whereby Muhammad predicted a special role for the Maghrib. ${ }^{46}$ Ibn Jubayr's (d. 614 H/1217 CE) Rihla reflects this new attitude of confidence and pride, and finds confirmation in the fact that, in a variety of ways, the Ayyūbids showed an inclination to Maghribi emigrant scholars and favoured them. ${ }^{47}$

Before Qāḍi 'Iyāḍ's time, it was by no means guaranteed that Andalusi and Maghribi scholars - no matter how relevant their contribution to Islamic learning and culture - would make their way into general țabaqāt and taräjim works, nor that their accomplishments would be celebrated or recorded. For example, Ibn al-Nadim's (d. 380 H/990 CE) Fihrist, a bio-bibliographical repertoire documenting authors and works known to him in Baghdad, includes only one author from Ifrīqiya. ${ }^{48}$ We have seen how the 3rd/9th-century geographer Ibn al-Faqin described the Maghrib as the worst part of the world, and, to be sure, it seems that in the Baghdadi cultural sphere there was a prevailing notion that the West had little to offer, ${ }^{49}$ an idea that still resonated in Ibn Khaldūn's (d. 808 H/1406 CE) time..$^{50}$ Andalusis and Maghribis often complained about this state of affairs, putting down in writing their conviction that in the East - and especially in Baghdad - their contributions were purposely ignored or dismissed. ${ }^{51}$ This conviction led some of them to record their achievements in the religious and intellectual domains, as in the case of Ibn Ḥazm's (d. 456 H/1064 CE) Risāla fi faḍl al-Andalus, which lists authors and titles intended to demonstrate that Andalusis were equal

46 "The inhabitants of the West (ahl al-gharb) will always be on the side of truth until the Hour comes”. See, for example, Dhikr bilād al-Andalus (1983), 15 (Sp. trans. 22). In Almohad times it acquired special saliency. See Buresi 2020.

47 Ibn Jubayr, Riḥla (1907), 278, 285; Ibn Jubayr, Rịlla (1952), 289, 298. See also Cahen 1973.

48 Maribel Fierro, “The Maghreb and al-Andalus in Ibn al-Nadīm's Fihrist”, paper presented at the 29th Conference of the Union Européenne des Arabisants et Islamisants, Münster University, 10-14 September 2018; see also Fierro 2018, 357, n. 2. One of the first biographical dictionaries to include Andalusi scholars was that of Ibn Mākūlā (d. 430 H/1038 CE); see Marín 1985. Before him, the Egyptian historian Ibn Yūnus (d. 347 H/958 CE) had written on the foreigners who travelled to Egypt, including Maghribis and Andalusis, but his work is lost (although there has been a recent attempt at reconstructing it on the basis of quotations by later authors). See Fierro 1987. 49 This is illustrated by a famous anecdote about the vizier al-Ṣāhib b. 'Abbād (d. 385 H/995 CE), whereby when an adab work by the Cordoban Ibn 'Abd Rabbihi (d. 328 H/940 CE), al- 'Iqd alfarìd (The Unique Necklace), fell into his hands, he exclaimed: "This is our merchandise brought back to us! I thought it would contain notices on their country (al-Andalus) but it merely contains notices about our own country. We do not need it!” See Yāqūt al-Ḥamawī, Mu 'jam al-udabā' (1414/1993), 1: 464; trans. by Toral-Niehoff 2015, 64.

50 Ibn Khaldūn, al-Muqaddima (2006-2007), 2: 180; Ibn Khaldūn, al-Muqaddima (1967), 2: 431. 51 As shown in the poems quoted at the beginning of this contribution. See also Fierro 2009; al'Āmirī 2015. 
and sometimes even superior to their Eastern counterparts. ${ }^{52}$ For all his pride in a (possibly made-up) Iranian background, Ibn Hazm was in fact not much interested in what the East had to offer - for example, in the field of theology, he was an acerbic critic of Ash'arī doctrines; ${ }^{53}$ he never performed the rihla and in his quotations of Prophetic traditions in his work al-Muhallā, he made a point of quoting local riwāyāt. The idea that former cultural centres could decline and new ones arise seems to have been very much present in 5th/11th-century al-Andalus, perhaps in connection with the collapse of the Cordoban Umayyad caliphate, and the myriad of new courts that arose in the newly formed taifa kingdoms. The decline of the 'Abbāsid caliphate also contributed to this appraisal, even under the Almoravids, who paid allegiance to them. Ibn al-Sīd al-Bațalyawsī (d. $521 \mathrm{H} / 1127 \mathrm{CE}$ ), who wrote a commentary on Ibn Qutayba's (d. 276 H/889 CE) Adab al-kātib, put it succinctly: li-kull dahr dawla wa-rijāl ('each period has its dynasty and its men'). ${ }^{54}$

One of Ibn Ḥazm’s students, al-Ḥumaydī (d. 488 H/1095 CE), left al-Andalus never to return and, having settled in Baghdad, became one of the mediators who helped integrate Andalusi and Maghribi scholarship into the worldview of Islam. He accomplished this in different ways, for example through his biographical dictionary of scholars, Jadhwat al-muqtabis fì dhikr wulāt al-Andalus wa-asmā' ruwāt al-hadìth wa-ahl al-fiqh wa-l-adab wa-dhawi al-nubāha wa-l-shi' $r$, which he wrote in Baghdad, having to rely heavily on his memory for lack of relevant sources in the local libraries. It was later used by Yāqūt al-Hamawī (d. 626 H/1229 CE), alDhahabī (d. 748 H/1348 CE) and al-Suyūṭi (d. 911 H/1505 CE)..$^{55}$ There is, however, little hard evidence that al-Humaydī was instrumental in spreading Ibn Hazm's works in the East. ${ }^{56}$ This is one Camilla Adang's conclusions in her contribution to this volume. In it she concentrates on al-Ḥumaydì’s al-Jam' bayn al-Ṣahịhayn, in which the author rearranged the traditions found in the hadith collections (Șahịh) of al-Bukhārī and Muslim. The book, although not the first in this genre, was much praised. As shown by Adang, from the 5th/11th century to the 9 th $/ 15$ th century it was constantly being copied, studied, taught, excerpted and commented upon by members of all four Sunnì schools of law, and to a lesser extent

52 Pellat 1954.

53 Schmidtke 2012.

54 Ibn al-Sīd al-Bațalyawsī, al-Iqtiḍāb (1996), 1: 138; see also Soravia 2019.

55 Al-Najmī 2015.

56 In addition to the influence of Ibn Hazm's student Shurayh (d. 539 H/1144 CE) indicated by Adang in her contribution to this volume, Chodkiewicz 1991 has highlighted Muhyī al-Dīn Ibn 'Arabī's influential role in making the work and doctrines of the Andalusi Zāhirī school known in the East. 
also by Twelver Shī'î scholars, who used al-Ḥumaydī's work mainly for apologetical or polemical purposes, as a source for traditions about 'Alī and his family. Among the Sunnīs, Mālikīs were the ones who showed the least interest in alHumaydì's work, due on the one hand to the fact that the Jam ' was mainly transmitted in the Mashriq, where the Mālikīs were a minority, and on the other hand, because in the predominantly Māliki West one could find several works from the same genre by local scholars. The fact that al-Humaydi was associated with Ibn Hazm and Zāhirism may have been an additional reason for Mālikīs' reluctance to study and transmit the work.

It took some time for the science of Prophetic tradition and the Prophetic tradition itself to circulate in earnest in the West. There were exceptions, such as Abū 'Ubayd's (d. 224 H/838 CE) Gharīb al-hadìth, which enjoyed great popularity in the Maghrib since very early times. ${ }^{57}$ By the 4th/10th century, however, the transmission and study of hadith flourished, and soon this important branch of religious knowledge saw a great deal of local output. Khaoula Trad traces in her contribution both the history of the hadith-commentary tradition in the Maghrib and the impact that some of these hadith commentaries had on the rest of the Islamic world, focusing in particular on Qāọī 'Iyāḍ's Ikmāl al-Mu lim fì sharh Șahīh Muslim and on Abū al-'Abbās al-Qurțubī's (d. 656 H/1258 CE) al-Mufhim limā ashkala min talkhịs kitāb Muslim. These works reflect the fact that Șahịh Muslim seems to have been preferred over Șahịh al-Bukhārì in the western Islamic lands, one of many features that differentiated the Maghrib from the other regions. ${ }^{58}$ While Qāḍi 'Iyāọ’s Ikmāl al-Mu 'im was read and used by the famed Syrian author al-Nawawī (d. 676 H/1277 CE) in his Minhāj al-țālibīn, Abū al-'Abbās al-Qurțubī's works on both Muslim and al-Bukhārī (namely, Ikhtiṣār Șaḥị̣ alBukhārī) were used by Ibn Ḥajar al- 'Asqalānī (d. 852 H/1449 CE).

Importantly, Abū al-'Abbās al-Qurțubī settled in Egypt, where he taught and died. Having students in the East was a determining factor in establishing his fame and reputation, as was also the case with al-Ḥumaydī, Abū al-Qāsim alShāțibī and Ibn Sa'̄ìd al-Maghribī. ${ }^{59}$

Together with Qāḍī 'Iyāḍ, Abū al-Qāsim al-Shāṭibī (d. 590 H/1194 CE) is one of the most successful Andalusi/Maghribi authors of all times. ${ }^{60}$ Zohra Azgal highlights in her paper the profound impact that the field of Qur'ānic readings,

57 Abū 'Ubayd, Gharīb al-ḥadīth (2019).

58 As already noted by Goldziher 1967-71, 2: 234.

59 As already pointed by Takeshi Yukawa, who highlighted the importance of differentiating between two types of scholars: transit and settler. See Yukawa 1979.

60 Fierro (in press). 
as developed in al-Andalus, had on the Islamic East, a process that can be traced back to scholars such as Makkī b. Abī Țālib al-Qayrawānī (d. 437 H/1045 CE) and Abū 'Amr al-Dānī (d. 444 H/1053 CE), ${ }^{61}$ and one that culminated with Abū alQāsim al-Shātibì's versification of al-Dānī's al-Taysīr fì al-qirā'āt al-sab'. Known as al-Shâtibiyya, this didactic poem became "the teaching handbook's bestseller for Qur'ānic readings” as Azgal describes it. The spectacular development of the qirā'a $\bar{t}$ genre in al-Andalus deserves further study in order to explain why it happened when it happened: mostly in the 5th/11th century, reaching its peak in alAndalus in the 6th/12th century. ${ }^{62} \mathrm{Abu}$ al-Qāsim al-Shātibī left al-Andalus in $572 \mathrm{H} / 1176$ CE. Having settled first in Alexandria before moving on to Cairo, he devoted himself to teaching and transmitting Qur'ānic readings. In the tabaqāt books, Azgal has identified thirty-one of al-Shāțibì's students from different regions of the Islamic world, many of whom attained important positions that helped them spread their teacher's work on a large scale. The success of his work and the centrality it acquired in the pedagogical process across space and time explains the fact that in al-Qasțallānī’s (d. 923 H/1517 CE) book on al-Shātibì, the latter is presented as a wali, a saint who never sinned and was endowed with many divine gifts. Azgal has also identified a large number of copies of alShattibiyya and in her $\mathrm{PhD}$ dissertation will focus on studying the production of manuscripts of his work in order to clarify its uses and functions, as well as the process through which the Andalusi qirā'a àt school eventually prevailed in the Muslim world.

We have seen above that Abū al-Qāsim al-Shātibī left al-Andalus in $572 \mathrm{H} /$ $1176 \mathrm{CE}$, supposedly under the pretence of performing the hajj. In fact, it was not uncommon for scholars who found themselves in trouble with the authorities to use the pilgrimage as an excuse to leave the country, with the hope of returning once the political situation had settled down. In the meantime they also accumulated useful cultural capital, as the example of the reputed scholar Abū Bakr Ibn al-'Arabī (d. $543 \mathrm{H} / 1148 \mathrm{CE}$ ) has shown. ${ }^{63} \mathrm{~A}$ century later, problems with the new Nașrid ruler made Ibn Sa 'īd al-Maghribī and his father decide to leave al-Andalus in 636 H/1238-9 CE for the East, as explained by Iria Santás de Arcos in her contribution. She focuses on the continuous writing and rewriting of Ibn Sa '̄id's most famous book, al-Mughrib fi hulā al-Maghrib, in terms of its sources, its authorship by different members of the same family, its structure and methodology, and its

61 Nasser 2013.

62 This has been shown by Zanón 1997, 556.

63 Garden 2015. 
impact on the East. ${ }^{64}$ While in Egypt, the Ayyūbid ruler al-Malik al-Ṣālih (d. $647 \mathrm{H} / 1249 \mathrm{CE}$ ) gave Ibn Sa īd access to the royal libraries and in $640 \mathrm{H} / 1243 \mathrm{CE}$ he was able to complete a first version that was very well received in Cairo. An important moment in Ibn Sa '̄id's life that contributed to the dissemination of his work was the year $644 \mathrm{H} / 1246 \mathrm{CE}$, when he met the scholar Ibn al-'Adim (d. $660 \mathrm{H} / 1262 \mathrm{CE}$ ) and left Cairo to accompany him to Aleppo. From there he went on to Damascus, Homs, Mosul, Baghdad, Basra, Armenia, Mecca and Iran. In $675 \mathrm{H} / 1276 \mathrm{CE}$ he finally returned to Tunis, where he stayed until his death in 685 H/1286-7 CE. Besides Ibn Sa'īd himself, three other scholars played a prominent role in the spread of the Mughrib: Muhammad b. Hamūshk al-Tinmalī, Sharaf al-Dīn Abū al-'Abbās Aḥmad b. Yūsuf al-Tīfāshī, and Ibn al-'Adīm. For Mamlūk authors the Mughrib constituted a valuable source, especially the part covering al-Andalus and North Africa. However, not many copies appear to have existed; today there is only one extant manuscript, preserved at Dār al-kutub almișriyya in Cairo, which seems to have been produced by the author himself. Later, this copy reached al-Ṣafadī's (d. $764 \mathrm{H} / 1363 \mathrm{CE}$ ) hands and those of other scholars, including Ibn Duqmāq (d. 809 H/1407 CE). The notes they left in the copy confirm that at the end of the 8th/14th century the manuscript was already in Cairo. Of fundamental importance in this process was the presence of a copy (perhaps the one preserved today) in the 9th/15th century in the library of the $\mathrm{Mu}$ 'ayyadiyya, which granted many scholars access to it, thus rendering the production of new copies less necessary. A number of other copies are known to have existed, in particular those made by Ibn Hamūshk and perhaps by al-Tīfāshī, but no Maghribi manuscript has been preserved.

Verses included in Ibn Sa 'īd's Mughrib were transmitted orally, having been committed to memory. The ways in which poetry spreads are not always easy to trace, just as it is not always apparent why specific poems or verses struck a chord with audiences of the past. An Andalusi invention in strophic poetry, the $m u$ washshaha, is a case in point. Brought by Andalusi/Maghribi travellers to Egypt, Syria, Iraq and beyond, the muwashshahāt were embraced outside their place of origin in the second half of the 5th/11th century and especially during the 6th/12th century. ${ }^{65}$ Ibn Khaldūn wrote how much the Easterners liked these poetic compositions, ${ }^{66}$ but gave no explanation as to why. Ibn Ẓāfir al-Ḥaddād (d. ca.

64 On the impact of Andalusi works on the literary field under the Mamlūks see Sālim al-Nawāfa'a 2008.

65 Afandī 1999. As for the related form of the zajal, see Özkan 2018.

66 Ibn Khaldūn, al-Muqaddima (2006-2007), 2: 566-602; Ibn Khaldūn, al-Muqaddima (1967), 3: $440-480$. 
525 H/1131 CE), an Egyptian Fātimid poet from Alexandria, composed at least two muwashshahāt that seem to be the earliest examples from the East. Teresa Garulo's contribution concentrates on a specific muwashshaha by 'Ubāda b. Mā' al-Samā' (d. 421 H/1030 CE). His muwashshahāt were a novelty within the new genre, as he was the first poet to insert internal rhymes in the parts of the poem called the aghșān; so successfully, in fact, that the previous rhyme schemes seem to have been forgotten. In Mamlūk Egypt and Syria, Cordoban poet 'Ubāda b. Mā' al-Samā's muwashshaha beginning with the words "Man walı" became hugely popular, and yet there is no trace of it in Andalusi or Maghribi sources. Perhaps al-Ḥumaydī, whose teacher Ibn Hazm praised 'Ubāda's book on the poets of alAndalus in his Risāla fi fachl al-Andalus, was instrumental in transmitting it eastward. Ten emulations ( $m u$ 'âraḍăt) of Man walī were produced in Syria and Egypt, in addition to one by a Yemeni poet, from the 6th/12th century all the way to the 20th century. Nobody found it necessary to explain why this poem attracted such attention. It probably had a musical accompaniment: Kallilī, the mu'ārada by Ibn Sanā' al-Mulk (d. 608 H/1211 CE) - or Muẓaffar al-'Aylānī (d. 623 H/1226 CE) - was sung from the beginning, and continues to be sung even today. As an Andalusi song, Kallilì's prelude and first strophe appear in Kunnāsh al-Hāàik, the compilation of the texts of songs deriving from Andalusi music still sung during the lifetime of its author, Muhammad al-Andalusī al-Tițwānī (12th/18th century). Perhaps the music itself was the greatest attraction of the muwashshahāt.

\section{Part IV: Pathways of Reception from the Maghrib to the Mashriq}

Ibn Khaldūn pointed to the linguistic barriers to Easterners' appreciation of the zajals written by Andalusis because they were written in Andalusi colloquial Arabic. Likewise, among the texts that travelled with the scholars from al-Andalus and the Maghrib, those dealing with pharmacology involved foreign medical terms that required identification and clarification. Juan Carlos Villaverde Amieva concentrates in his paper on the Andalusi Romance terms found in the book by the physician 'Izz al-Dīn Abū Ishāa b. Muhammad b. Țarkhān al-Suwaydī (or Ibn al-Suwaydī) (d. 690 H/1291 CE), Kitāb al-Simāt fì asmā' al-nabāt, a repertory of names of simple medicines that is known for its linguistic richness. Arabic and its numerous dialectal variants is the language best represented in it, together with other languages from the Middle East (Nabataean, Coptic) and other geographical regions (Nubia, Armenia, the land of the Turks, Greek...), as well as 
Berber. Al-Suwaydī's references to al-Andalus exceed by far his references to any of the other regions, including the author's native Syria. These are references to different plants or medicinal substances found in the Iberian Peninsula and to these substances' Andalusi names and synonyms. The information provided reflects an Arabic/Romance duality in al-Andalus that, however, does not necessarily reflect a persistent bilingualism in al-Suwaydī's times. In fact, together with the Arabic terms used specifically by Andalusi botanists, some of which belong to the Andalusi dialect, there are also references to their synonyms in Romance, generally referred to as laținiyya ('Latin'), but also as 'ajamiyyat al-Andalus. Al-Suwaydì's source is the famed Andalusi botanist Ibn al-Bayțār (d. 646 H/ $1248 \mathrm{CE}$ ), and his book is another piece of evidence to add to our knowledge of the extraordinary textual dissemination of Ibn al-Bayțār's pharmacological work. There are many copies of his Kitāb al-Mughnī fì al-adwiya al-mufrada and even more of his Kitāb al-Jāmi' li-mufradāt al-adwiya wa-l-aghdhiya. ${ }^{67}$ These books must have already become widely distributed during their author's lifetime, especially in Damascus where Ibn al-Bayțār settled and died, and where al-Suwaydī may have studied with him.

The 7th/13th-century catalogue of the Ashrafiyya Library in Damascus has revealed that books from the western Islamic world were abundant in the original collection, either brought to Damascus by Maghribi travellers, or transcribed in Syria by Maghribi migrants. ${ }^{68}$ We have also seen how the first non-Andalusi $m u$ washshahāt were written in Alexandria, a Mediterranean commercial entrepôt where many Muslims, Christians and Jews from inside and outside dār al-islām arrived both by land and by sea. ${ }^{69}$ Like other port cities, Alexandria was transregional, trans-religious and trans-cultural, a trading zone in which knowledge flowed in all directions. How did the transmission of knowledge interplay with long-distance trade routes, different forms of economic exchange and flows of merchants, pilgrims and travellers in general $?^{70}$

Some of these travellers were mystics from the Maghrib and al-Andalus, from such towering figures as Muhyī al-Dīn Ibn al-'Arabī (d. 638 H/1240 CE) down to minor saints. ${ }^{71}$ José Bellver studies in his paper a specific case of the vast influence that Andalusi and Maghribi Șūfism had outside the Iberian Peninsula, an

67 Fierro (in press).

68 Hirschler 2016, 38 (the works of Ibn al-Bayțār and of Ibn Sab'īn's son, studied by Bellver, are not listed).

69 Walker 2014.

70 Marín 1998-99.

71 Ṣafì al-Dīn ibn Abī al-Manșūr, Risāla (1986); Marín 1994. 
influence that affected not only Muslims but also other religious communities, especially the Jews. ${ }^{72}$ Yahyā b. 'Abd al-Haqq b. Sab'īn was the son of the most renowned intellectual mystic born in al-Andalus after Ibn al-'Arabī, Ibn Sab'in (d. 668 or 669 H/1270-1 CE), who had settled in Mecca, where he lived until his death. Thus, his son Yaḥyā may therefore have been born in the East. Yaḥyā b. 'Abd al-Haqq b. Sab'īn's Kitāb al-Sulūk fì țarīq al-qawm - edited and translated by Bellver - is a short Șūfĩ text that summarizes some of his father's insights into Șufism, developing the concept of muhaqqiq and depicting some metaphysical correspondences of the pair muhaqqiq/murìd, i.e. realizer/aspirant. Although written from a Neoplatonic perspective, it manages to avoid the use of philosophical terminology. The only known manuscript is preserved today at the Süleymaniye library in Istanbul. Its copyist was 'Abd al-Qādir b. Muṣțafā al-Ṣafūrī alDimashqī (d. 1081 H/1670 CE), the teacher of the Șūfī scholar 'Abd al-Ghanī alNābulusī (d. 1143 H/1731 CE), thus providing a new context for the latter's interest in Ibn Sab'īn.

Textual transmission as explored in the previous contributions is also present in Kentaro Sato's study of how Ibn Khaldūn presented himself in Mamlūk Cairo as a Maghribi scholar in possession of a Maghribi tradition of knowledge. In his first lecture on Mālik b. Anas’s (d. 179 H/796 CE) Muwaț̣a' at the Șarghitmish madrasa in Cairo, he made use of an isnād in which only Maghribi and Andalusi scholars appeared as transmitters, stretching back to Yahyā b. Yahyā al-Laythī's (d. $234 \mathrm{H} / 849 \mathrm{CE}$ ) riwāya, the quintessential 'Western' recension of the foundational text of the Mālikī legal school. As pointed out by Sato, almost no Mashriqi - including Egyptian - scholars ever went to the Maghrib to study this riwāya. Those who were interested - such as Ibn Ḥajar al-'Asqalānī - could study it in Cairo under Maghribi scholars, but its value was limited in the Egyptian context, where it lacked the strong emotional resonance it had in the Maghrib. Moreover, it had to compete with other recensions that attached Mālik b. Anas's Muwatța' to other regional contexts.

One of Ibn Hajar's teachers had an isnād of Mālik's Muwațta' that went back to the Andalusi Abū Bakr al-Ṭurțūshī (d. 520 H/1126 CE), a seminal figure in the re-establishment of the Mālikī legal school in Egypt after he settled in Alexandria. The presence of Mālikī jurists from the Maghrib and al-Andalus in post-Fātịmid Egypt is studied by Maribel Fierro in her paper. Statistics drawn from the tabaqāt works by Qāḍī 'Iyāọ and Ibn Farhūn (d. 799 H/1397 CE) clearly show that the Ayyūbid and Mamlūk periods saw an increase in the numbers of Mālikīs, some of whom were of Maghribi origin. Whatever their background, the Egyptian Mālikīs

72 Wasserstrom 2000. 
who left behind a written production could not but refer in their works to the Andalusi/Maghribi Mālikī tradition. However, Baybars's novel 663 H/1265 CE creation of four judgeships representing the four Sunnī legal schools led to a specific development, which Mohammed Fadel has called "the rise of the mukhtașars", ${ }^{73}$ legal handbooks that offered the predominant doctrine of the school to be applied in the judicial court. Because this predominant doctrine had most often been established in the Maghrib, one would expect the Maghribi Mālikīs to have welcomed the mukhtașars with open arms. However, the introduction of the mukhtașar genre from Egypt to the Maghrib coincides with the composition of numerous compilations of Māliki fatāwa - a genre that is absent among the Egyptian Mālikīs. Fierro's proposal is to see in such activities a way of deflecting the potential impact of the Egyptian mukhtașars on the Maghrib.

The impact that Andalusi and Maghribi Mālikism had in West Africa is well known, given the north-south direction of the process of Islamization in the region. ${ }^{74}$ Adday Hernández's contribution focuses on a less explored area, the Horn of Africa, and on more recent times (19th and 20th centuries). Works from the Islamic West represented in the libraries and collections selected are classified into five categories: Sūfism and theology; linguistics and grammar; Qur'ānic sciences; jurisprudence; and others, including $a d a b$ and medicine. As one might expect, her research has turned up an abundance of basic summarized texts on easy-to-memorize subjects, such as versified didactic works, which were very common in al-Andalus and the Maghrib. Specifically, we find Ibn Farah's (d. 699 H/1300 CE) poem on 'ilm al-ḥadith, the Shāțibiyya, Ibn Mālik's (d. 672 H/ 1273 CE) Alfiyya, and al-Sanūsī’s (d. 895 H/1490 CE) Umm al-barāhīn. A Mālikī legal manual that falls into this category of user-friendly and easy-to-consult books, Ibn Abī Zayd al-Qayrawānī's (d. 386 H/996 CE) Risāla fi al-fiqh, is also represented. The establishment of the Tijāniyya order in the area explains the presence of certain Șūfi works that travelled mainly from Mecca-Yemen and secondarily from Egypt-Sudan. The two most popular Șūfi works throughout the Horn - both of Maghribi origin - are al-Jazūlī's (d. 869 H/1465 CE) Dalā'il al-khayrāt and Ibn 'Azzzūm's (d. 960 H/1552 CE) Tanbìh al-anām, consisting of collections of prayers for the Prophet Muhammad. The works studied represent around ten percent of those catalogued within the project Islam in the Horn of Africa: A comparative literary approach (dir. Alessandro Gori), that is, approximately 200 out of the more than 2,000 works analysed.

73 Fadel 1996.

74 See Anderson 1954, and more generally Usman 2009. 


\section{Part V: Remaining Maghribi while in the Mashriq}

Andalusi identity in different areas and from different perspectives has been the subject of a number of studies. ${ }^{75}$ For example, focusing on the specific field of astronomy, Abdelhamid I. Sabra has stated that "the Andalusian sense of identity went further than self-praise and actually expressed itself in the creation of systems of ideas that were distinctly Andalusian and consciously directed against intellectual authorities in the Eastern part of Islam". ${ }^{76}$ The case of the Maghrib, however, is more complex, as it covers a broader geographical area and a variety of different polities, at times even encompassing al-Andalus, as was the case during the period of the Berber empires. Travelogues by Andalusi and Maghribi authors, then, are one tool that offers particular insight into how these travellers viewed themselves. ${ }^{77}$ For example, famous Jewish Andalusi thinker Mūsā b. Maymūn al-Qurțubī, better known as Maimonides (d. 1204), discusses the regional divide in explicit terms, highlighting the difference between the customs in Egypt, where he finally settled, and those "chez nous in the West ('indana fi almaghrib)". ${ }^{78}$

In his contribution, Umberto Bongianino offers a preliminary survey of manuscripts that reveal Maghribi emigrants' use of their local scripts as enduring vehicles of cultural identity in the Mashriq. Some of these manuscripts were brought from back home in the West, while others were produced in the East, and all of them were read, annotated, and deposited in the mosques and madrasas of the eastern Islamic Mediterranean between the 6th/12th century and the 7 th/13th century (in Bongianino's study we once again see the crucial role of Alexandria). The distinctive appearance of such manuscripts reflects the intellectual pursuits and identity of scholars for whom the use of Maghribi scripts was a way to maintain a link with the cultural background from which they came. It was a trait they shared with others, and a link that was not at odds with adaptation and even acculturation to their new contexts, as with some of Muhyī al-Dīn Ibn al-'Arabī's autograph manuscripts, whose script and layout include a number of distinctive Mashriqi features.

Josef Ženka's contribution also revolves around manuscripts and identity, being part of a wider, innovative and seminal research project that is recovering the manuscript legacy of Nașrid Granada. In this case, he concentrates on a

75 For example, in Martínez-Gros 1997; Marín 1999; Weber 2000; Marín 2001.

76 Sabra 1984, 143. Cf. for the field of grammar Carter 2011.

77 Ferhat 2001; Marín 2005; Ghouirgate 2010; Calasso 2014.

78 López Lázaro, 2013, 263, quoting Anidjar 2002. See also Brann 2000 and Alfonso 2008. 
unique manuscript - a holograph of the Marīnid Chancellor Muhammad Ibn Ḥizb Allāh al-Wādī Āshī (d. 788 H/1386 CE) - that offers a valuable example of how Maghribis in the East represented themselves and were represented by others. By skilfully combining different types of source material, Ženka opens up new possibilities for assessing the cultural acts of expression that migrants performed according to their context and the persons involved, and the transformations in meaning that writings were subject to in time and space. In these circumstances, the evidence of how these migrants related to one other is of particular interest.

Takao Ito brings us back to another famous Maghribi, Ibn Khaldūn (d. $808 \mathrm{H} / 1406 \mathrm{CE}$ ), paying attention to the biographies written by his contemporary and near-contemporary authors. He shows how Maghribi sources from the 9th10th/15th-16th centuries refer to him less than those produced in the East, especially in the Mamlūk sultanate. Ibn Ḥajar al-'Asqalānī - who as noted above was partial to the Maghribi isnād of Mālik's Muwațta' - criticized Ibn Khaldūn for stubbornly clinging on to Maghribi-style clothing instead of adopting the clothes worn by Egyptian judges.

\section{Next steps forward}

The Eastern legal scholar and theologian al-Juwaynī (d. 478 H/1085 CE), when dealing with the nature and requirements of consensus (ijm $\bar{a}$ ), defined it as "the consensus of all those upon whom the sun has shone in the East and the West and by the agreement of the views of all scholars collectively" ${ }^{79}$ This inclusive attitude in the fields of law and theology was not always paralleled in other spheres: of Ibn Dihya (d. $633 \mathrm{H} / 1235 \mathrm{CE}$ ) it is said that he wrote his Mutrib min ash'är ahl al-Maghrib because Eastern authors of poetic anthologies routinely excluded poets from the West. ${ }^{80}$ The engagement of Eastern scholars with the knowledge produced in the West took some time, one of the first cases being the writing of a refutation of the Cordoban Ibn Masarra's (d. 319 H/931 CE) works by the Eastern author Abū Sa īd Ibn al-A'rābì (d. 341 H/952 CE). This started a long chain of such reactions that later included, for example, al-Dhahabì's refutation of Ibn al-Qațțān's (d. 628 H/1231 CE) commentary on Ibn al-Kharrāț's (d. 581 or 582 H/1185-6 CE) al-Aḥkām, al-Radd 'alā Ibn al-Qațtān fì kitābihi Bayān al-wahm

79 Al-Juwaynī, Ghiyāth al-umam (1401/1980), 23; trans. by Hassan 2016, 101.

80 Gallega Ortega 2004, 66. 
wa-l-īhamm. ${ }^{81}$ The study of this type of works - especially when not limited to big names such Muhyī al-Dīn Ibn al-'Arabī and Ibn Khaldūn - will do much to advance our knowledge about the reception of Andalusi/Maghribi intellectual production outside the Maghrib. Attention should be paid not only what was rejected, but also to what was absorbed or found useful, as in the case of Ibn Taymiyya's use of Ibn Rushd..$^{82}$ There is certainly room for a monograph on the inclusion of Andalusi/Maghribi scholars in Eastern biographical dictionaries, ${ }^{83}$ and about Eastern scholars who travelled to the Maghrib. ${ }^{84}$ We have already mentioned the question of how the transmission of knowledge interplayed with longdistance trade routes, different forms of economic exchange, and the flows of merchants, pilgrims and travellers in general. In terms of the wave of migration to the East that took place especially from the 6th/12th century onwards, a study is needed into any networks of solidarity that the emigrants may have established, as well as the consequences that this 'brain drain' had on the Maghrib. The impact that the emigrants had outside scholarly circles is also in need of study.$^{85}$ Finally, a comparative perspective with similar processes affecting other regions of the Islamic world would considerably enrich our understanding of the case of the Maghrib. It is our hope to continue this project over the coming years in order to produce some of the studies here listed as desiderata.

\section{Bibliography}

\section{Primary sources}

'Abd Allāh b. Buluggīn al-Zīrī (1995), al-Tibyān li-l-amīr 'Abd Allāh b. Buluqqīn, ed. by Amīn Tawfīq al-Ṭibī, Rabat: Manshūrāt 'Ukāẓ.

'Abd Allāh b. Buluggīn al-Zīīi (1986), al-Tibyān, trans. by Amin T. Tibi, The Tibyān. Memoirs of 'Abd Allāh b. Buluggīn last Zīrid Amīr of Granada, Leiden: Brill.

81 These and other refutations can be found in HATA.

82 Hoover 2018.

83 See above notes 41 and 42. The materials already collected in the series $E O B A$ will be of much help, as well as studies such as Ibrāhīm 2002.

84 For al-Andalus, a preliminary study of the topic was carried out by Estefanía González during her stay at the Institute of Languages and Cultures of the Mediterranean, CSIC, with a JAE-Intro grant (2019). For the case of the Maghrib, see Sciortino 2010.

85 Cf. Frenkel 2008, 14. 
Abū 'Ubayd al-Qāsim b. Sallām (2019), Gharīb al-ḥadīth, ed. by Mohamed Mokhtar Labidi, alGarîb al-Mușannaf (La somme des vocables rares), Tunis: Académie Tunisienne des Sciences des Lettres des Arts Beït al-Hikma.

Dhikr biläd al-Andalus (1983), ed. and trans. by Luis Molina, 2 vols., Madrid: CSIC.

Ibn Abī Shayba (1966-1983), Muṣannaf, ed. by 'Abd al-Khāliq Khān al-Afghānī et al., 15 vols., Hyderabad - Bombay.

Ibn Bassām (1978-1981), al-Dhakhīra fĩ maḥāsin ahl al-Jazīra, ed. by Ị̣sān 'Abbās, 8 vols., Libya - Tunis: al-Dār al-'Arabiyya li-l-Kitāb.

Ibn Diḥya (1429/2008), al-Muțrib min ash'ār ahl al-Maghrib, ed. by Șalāḥ al-Dīn al-Hawwārī, Beirut: al-Maktaba al-'Așriyya.

Ibn al-Haytham (2000), Kitāb al-Munāzarāt, ed. and trans. by Wilferd Madelung and Paul E. Walker, The Advent of the Fatimids. A Contemporary Shii Witness, London: IB Tauris.

Ibn Ḥazm (1978), Ṭawq al-ḥamāma fí al-ulfa wa-l-ullāf, ed. by lḥsān 'Abbās, Beirut: al-Mu'assasa al-'Arabiyya li-l-Dirasāt wa-l-Nashr.

Ibn Ḥazm (1953), Ṭawq al-hamāma, trans. by A. J. Arberry, The Ring of the Dove, London: Luzac \& Company.

Ibn Jubayr (1907), Rihla, ed. by W. Wright, The Travels of Ibn Jubayr, Edited from a MS. in the University Library of Leyden (second edition revised by M. J. de Goeje), Leiden - London: Brill - Luzac \& Co.

Ibn Jubayr (1952), Riḥla, trans. by R. J. C. Broadhurst, The Travels of Ibn Jubayr, London: Jonathan Cape.

Ibn Khaldūn (2006-2007), al-Muqaddima, ed. by Ibrāhīm Shabbūḥ and lḥsān 'Abbās, Kitāb al'Ibar wa-dīwān al-mubtada' wa-l-khabar fí ayyām al-'arab wa-l-'ajam wa-l-barbar wa-man 'āṣarahum min dhawī al-sulțān al-akbar. Al-Kitāb al-awwal: al-Muqaddima, 2 vols., Tunis: Dār al-Qayrawān li-l-Nashr.

Ibn Khaldūn (1967), al-Muqaddima, trans. by Franz Rosenthal, The Muqaddimah. An Introduction to History, 3 vols., Princeton, N): Princeton University Press.

Ibn Shuhayd (1969), Dīwān Ibn Shuhayd al-Andalusī, ed. by Ya'qūb Zakī (James Dickie), Cairo: Dār al-Kātib al-'Arabī.

Ibn al-Sīd al-Bațalyawsī (1996), al-lqtị̣āb fĩ sharḥ adab al-kuttāb, ed. by Mușțafā al-Saqqā and Ḥāmid 'Abd al-Majīd, 3 vols., Cairo: Dār al-Kitāb al-Miṣriyya.

Al-Juwaynī (1401/1980), Ghiyāth al-umam fĩ iltiyāth al-ẓulam, ed. by 'Abd al-'Az̄īm al-Dīb, Cairo: Mațba'at Nahụat Miṣr.

Al-Maqqarī (1968), Kitāb Nafḥ al-țīb min ghuṣn al-Andalus al-rațīb, ed. by lḥ̂ān 'Abbās, 8 vols., Beirut: Dār Șādir.

Șafī al-Dīn ibn Abī al-Manșūr (1986), Risāla, ed. and trans. by Denis Gril, La Risāla de Șafĩ alDīn ibn Abī l-Manșūr ibn Ẓāfir. Biographies des maîtres spirituels connus par un cheikh égyptien du VIIe/XIIle siècle, Cairo: Institut français d'archéologie orientale.

Yāqūt al-Ḥamawī (1414/1993), Mu'jam al-udabā'. Irshād al-arīb ilā ma'rifat al-adīb, ed. by lḥsān 'Abbās, 7 vols., Beirut: Dār al-Gharb al-Islāmī. 


\section{Secondary sources}

Adil, Sabahat F. (2019), “Scholarship, space, and strategies of belonging in al-Maqqarī’s (d. 1031/1632) literary and historical writings", The Journal of North African Studies 24, 717737.

Afandī, Majd (1999), al-Muwashshahāt al-mashriqiyya wa-athar al-Andalus fïhā, Damascus: Dār al-Fikr.

Aillet, Cyrille (forthcoming), “'Dieu ouvrira une nouvelle porte pour l'islam au Maghreb' : Ibn Sallām (III ${ }^{\mathrm{e}} / \mathrm{IX}^{\mathrm{e}}$ siècle) et les hadiths sur les Berbères, entre Orient et ibadisme maghrébin”, in: Dominique Valérian, ed., Les Berbères entre Maghreb et Mashreq, Madrid: Casa de Velázquez.

Akmaluddin, Muhammad (2017), "Developments of Ḥadīth riwāya in al-Andalus (2nd-3rd centuries of hijriyya)", Ulumuna 21/2, 228-252.

Albarrán, Javier (in press), "From the Islamic West to Cairo: Malikism, Ibn Tūmart, al-Ghazāī and al-Qāḍī 'lyāọ’s death”, in: María Marcos Cobaleda, ed., Artistic and Cultural Dialogues in the Late Medieval Mediterranean, Palgrave MacMillan.

Alfonso, Esperanza (2008), Islamic Culture Through Jewish Eyes: al-Andalus from the Tenth to Twelfth Century, London - New York: Routledge.

Al-'Āmirī, Muḥammad Bashīr (2015), Baghdād fĩ 'uyūn al-'ulamā' wa-qulūb al-āmma fĩ al-Andalus, Amman: Dār al-Manāhij li-l-Nashr wa-l-Tawzī‘.

Anderson, Norman (1954), Islamic Law in Africa, London: Her Majesty's Stationery Office.

Anidjar, Gil (2002), “Our Place in al-Andalus”. Kabbalah, Philosophy, Literature in Arab Jewish Letters, Stanford: Stanford University Press.

Ávila, María Luisa (1985), “Nuevos datos sobre la biografía de Baqī b. Majlad”, Al-Qanțara 6, 321-367.

Baadj, Amar S. (2019), “Travel by Sea and Land between the Maghrib and the Mamluk Empire”, in: Reuven Amitai and Stephan Conermann, eds., The Mamluk Sultanate from the Perspective of Regional and World History. Economic, Social and Cultural Development in an Era of Increasing International Interaction and Competition, Göttingen: V\&R unipress GmbH, 279-306.

Benelhaj Soulami, Jaafar (2014), “La imagen de los almohades en Oriente, al-Andalus y el Magreb (515-609h/1121-1212j-c)”, in: Patrice Cressier and Vicente Salvatierra, eds., Las Navas de Tolosa (1212-2012). Miradas cruzadas, Jaén: Universidad de Jaén, 89-104.

Benhima, Yasir (2009), “al-Marrākušī, 'Abd al-Wāḥid”, in: Jorge Lirola Delgado, ed., Biblioteca de al-Andalus 6: De Ibn al-Ŷabbāb a Nubdat al-'așr, Almería: Fundación Ibn Tufayl de Estudios Árabes, 512-514, no. 1531.

Borrut, Antoine / Cobb, Paul M. (2010), Umayyad Legacies. Medieval Memories from Syria to Spain, Leiden: Brill.

Brann, Ross (2000), “'How Can My Heart be in the East?' Intertextual Irony in Judah ha-Levi”, in: Benjamin H. Hary, John L. Hayes and Fred Astren, eds., Judaism and Islam: Boundaries, Communication, and Interaction. Essays in Honor of William M. Brinner, Leiden: Brill, 365-379.

Bray, Julia (2019a), “Picture-poems for Saladin: 'Abd al-Mun 'im al-Jilyān̄’s mudabbajāt”, in: Carole Hillenbrand, ed., Syria in Crusader Times: Conflict and Co-Existence, Edinburgh: Edinburgh University Press, 247-264. 
Bray, Julia (2019b), “From Spain to Syria: What did al-Jilyānī bring with him?”, in: Antonio Pellitteri, Nesma Elsakaan, Maria Grazia Sciortino and Daniele Sicari, eds., Re-Defining a Space of Encounter. Islam and Mediterranean: Identity, Alterity and Interactions: Proceedings of the 28th Congress of the Union Européenne des Arabisants et Islamisants, Palermo 2016, Leuven - Paris - Bristol: Peeters, 2019, 105-114.

Bulliet, Richard W. (1994), Islam. The View from the Edge, New York: Columbia University Press. Buresi, Pascal (2020), "Berber rule and the Maghribi caliphate. The Almohads", in: Maribel Fierro, ed., The Routledge Handbook of Muslim Iberia, Abingdon, Oxon - New York: Routledge, 114-144.

Cahen, Claude (1973), “Ibn Jubayr et les Maghrébins de Syrie”, Revue de l'Occident musulman et de la Méditerranée 13-14, 207-209.

Calasso, Giovanna (2014), “Egypt through Maghrebi eyes: al-'Abdarî’s Rihla between Ibn Jubayr and Ibn Khaldūn”, Rivista degli Studi Orientali (nuova serie) 87, 201-209.

Calasso, Giovanna / Lancioni, Giuliano, eds. (2017), Dār al-islām/dār al-ḥarb: Territories, People, Identities, Leiden: Brill.

Calderwood, Eric (2018), Colonial al-Andalus: Spain and the Making of Modern Moroccan Culture, Cambridge, MA: Harvard University Press.

Carter, Michael G. (2011), “The Andalusian Grammarians, Are They Different?”, in: Bilal Orfali, ed., In the Shadow of Arabic: The Centrality of Language to Arabic Culture. Studies Presented to Ramzi Baalbaki on the Occasion of His Sixtieth Birthday, Leiden - Boston: Brill, 31-48.

Chapoutot-Remadi, Mounira (1979), “Les relations entre l'Égypte et l'Ifriqya aux XIII et XIVe siècle d'après les auteurs Mamlûks”, in: Actes du Premier Congrès d'Histoire et de la Civilisation du Maghreb, Tunis: Université de Tunis, Centre d'Études et de Recherches Économiques et Sociales, 1: 139-159.

Chodkiewicz, Michel (1991), “The Diffusion of Ibn 'Arabi’s Doctrine”, Journal of the Muhyiddin Ibn 'Arabi Society 9, 36-57.

Curta, Florin (2011), "Introduction. The centrality of the periphery: the archaeology of al-Andalus", Early Medieval Europe 19/4, 377-384.

Al-Darwīsh, Jāsim Yāsīn (2015), al-Andalus min al-Kāmil fĩ al-tārīkh li-lbn al-Athīr ( 630 H/1232 M), Damascus: Tammūz.

El Erian El Bassal, Hany (2013), “El oriente visto como alteridad por algunos viajeros andalusíes y magrebíes de los siglos XII-XIV", eHumanista/IVITRA 4, 266-284.

Elger, Ralf (2002), “Adab and Historical Memory. The Andalusian Poet/Politician Ibn al-Khațīb as Presented in Aḥmad al-Maqqarī (986/1577-1041/1632), Naf̣̣ aț-țīb”, Die Welt des Islams 42, 289-306.

El-Rouayheb, Khaled (2015), Islamic Intellectual History in the Seventeenth Century, Cambridge: Cambridge University Press.

El Shamsy, Ahmed (2020), Rediscovering the Islamic Classics. How Editors and Print Culture Transformed an Intellectual Tradition, Princeton - Oxford: Princeton University Press.

Fadel, Mohammed (1996), “The Social Logic of taqlīd and the Rise of the mukhtașar”, Islamic Law and Society 3, 193-233.

Felipe, Helena de (2018), “The Butr and North African Ibāọism: Praise and Criticism of the Berbers”, in: Cyrille Aillet, ed., L'ibadisme dans les sociétés de l'Islam médiéval: Modèles et interactions, Berlin - Boston: De Gruyter, 88-110. 
Ferhat, Halima (2001), “Les relations entre le Maghreb et l'Orient au Moyen Âge : pèlerinage, initiation et découverte de l'autre", in: Storie di viaggio e di viaggiatori. Incontri nel Mediterraneo (Atti del III Seminario internazionale della Commissione Nazionale Italiana per l'Unesco, Cagliari, 3-5 ottobre 1996), Cagliari: Tema, 77-85.

Fernández Félix, Ana (2003), Cuestiones legales del islam temprano. La Utbiyya y el proceso de formación de la sociedad islámica andalusí, Madrid: CSIC.

Fierro, Maribel (1987), “Ibn Yūnus, fuente de Ibn al-Faraḍī”, in: Homenaje al Prof. Darío Cabanelas Rodríguez O.F.M., Granada: Universidad de Granada, 1: 297-313.

Fierro, Maribel (1995), “La falsificación de la historia: al-Yasa' b. Ḥazm y su Kitāb al-mugrib”, Al-Qanțara 16, 15-38.

Fierro, Maribel (2009), “Entre Bagdad y Córdoba: centro y periferia en el mundo del saber islámico (siglos III/IX-VI/XII)", in: Salvador Peña, ed., Iraq y al-Andalus: Oriente en el Occidente islámico, Almería: Fundación Ibn Tufayl, 63-90.

Fierro, Maribel (2016), “El Mahdī Ibn Tūmart: más allá de la biografía ‘oficial’”, in: Miguel Ángel Manzano and Rachid El Hour, eds., Política, sociedad e identidades en el Occidente islámico (siglos XI-XIV), Salamanca: Ediciones Universidad de Salamanca, 73-98.

Fierro, Maribel (2018), "The Other Edge: the Maghrib in the Mashriq", in: Sabine Schmidtke, ed., Studying the Near and Middle East at the Institute for Advanced Study, Princeton, 1935-2018, Piscataway, N): Gorgias Press, 353-358.

Fierro, Maribel (2019), "Medina, the Mashriq and the Maghrib in the recension of Mālik's Muwațta' by the Cordovan Yaḥyā b. Yahyyā al-Laythī”, in: Mohamad Fadel and Connell Monette, eds., Online Companion to the book, al-Muwața' - Recension of Yaḥyā b. Yahyā (d. 234/848) by Mālik b. Anas, Harvard University Press, https://beta.shariasource.com/projects/muwattaonlinecompanion.

Fierro, Maribel (in press), “The 'Bestsellers' of al-Andalus”, in: María Marcos Cobaleda, ed., Artistic and Cultural dialogues in the Late Medieval Mediterranean, Palgrave-MacMillan.

Frenkel, Yehoshua (2008), “Popular Culture (Islam, Early and Middle Periods)”, Religion Compass 2, 1-31.

Gallega Ortega, T. (2004), “Ibn Diḥya, Abū l-Jațțāb”, in: Jorge Lirola Delgado and José Miguel Puerta Vílchez, eds., Biblioteca de al-Andalus 3: De Ibn al-Dabbāg a Ibn Kurz, Almería: Fundación Ibn Tufayl de Estudios Árabes, 63-69, no 435.

García Sanjuán, Alejandro (2003), “El significado geográfico del topónimo al-Andalus en las fuentes árabes”, Anuario de Estudios Medievales 33/1, 3-36.

Garden, Kenneth (2015), “The riḥla and Self-Reinvention of Abū Bakr lbn al-'Arabī”, Journal of the American Oriental Society 135/1, 1-17.

Gazi, al-Sayyid Mustafa (1953), “Ibn Diḥya en el Muțrib. Original y versión española”, Revista del Instituto Egipcio de Estudios Islámicos 1, 172-190.

Ghouirgate, Abdellatif (2010), “Les Maghrébins au Proche-Orient : une minorité visible ?”, in: Stéphane Boissellier, François Clément and John Tolan, eds., Minorités et régulations sociales en Méditerranée médiévale. Actes du Colloque réuni du 7 au 9 juin 2007 en l'Abbaye royale de Fontevraud (Maine-et-Loire), Rennes: Presses Universitaires de Rennes, 207-222.

Ghouirgate, Mehdi (in press), “Al-Lisān al-garbĩ : la langue des Almohades”, in: Dominique Valérian, ed., Les Berbères entre Maghreb et Mashreq, Madrid: Casa de Velázquez.

Goldziher, Ignaz (1967-1971), Muslim Studies, trans. by C. R. Barber and S. M. Stern, 2 vols., London: George Allen \& Unwin Ltd. 
Hamdani, Sumaiya (2014), “Worlds apart? An Andalusi in Fāțimid Egypt”, The Journal of North African Studies 19/1, 56-67.

Hassan, Mona (2016), Longing for the Lost Caliphate: A Transregional History, Princeton - Oxford: Princeton University Press.

Hirschler, Konrad (2016), Medieval Damascus. Plurality and Diversity in an Arabic Library. The Ashrafiya Library Catalogue, Edinburgh: Edinburgh University Press.

Hoover, Jon (2018), “Ibn Taymiyya's Use of Ibn Rushd to Refute the Incorporealism of Fakhr alDīn al-Rāzī”, in: Abdelkader Al Ghouz, ed., Islamic Philosophy from the $12^{\text {th }}$ to the $14^{\text {th }} \mathrm{Cen}$ tury, Göttingen: Bonn University Press/V\&R unipress, 469-491.

Ibn Tāwīt, Muḥammad (1402/1982), Tārīkh Sabta, Casablanca: Dār al-Thaqāfa.

Ibrāhīm, Rajab 'Abd al-Jawwād (2002), Mașādir al-Suyūțī fĩ al-tārīkh li-nuhāat al-Andalus: dirāsa tawthīqiyya fi ḍaw' Bughyat al-wu'āt, Cairo: Maktabat al-Ādāb.

Al-Ifrānī, Muḥammad al-Ṣaghīr (2000), Durar al-ḥijāl fí manāqib sab'at rijāl, ed. by Ḥasan Jallāb, Marrakesh: al-Mațba'a al-Wațaniyya.

ìnsanoğlu, Ekmeleddin (2015), "Scholars of Andalusian Origin and their Contribution to Ottoman Science", Suhayl 14, 9-48.

Jebari, Idriss (2015), The production of critical thought in the Maghrib in the sixties and seventies: Abdallah Laroui and Hichem Djaït (1965-1978), PhD dissertation, University of Oxford.

Küçük, Hülya (2013a), “Light upon Light in Andalusī Sufism: Abū l-Ḥakam Ibn Barrajān (d. 536/1141) and Muhyī l-Dīn Ibn al-'Arabī (d. 638/1240) as Developer of His Hermeneutics. Part 1: Ibn Barrajān's Life and Works”, Zeitschrift der Deutschen Morgenländischen Gesellschaft 163/1, 87-116.

Küçük, Hülya (2013b), “Light upon Light in Andalusī Sufism: Abū l-Ḥakam Ibn Barrajān (d. 536/1141) and Muhyyī l-Dīn Ibn al-'Arabī (d. 638/1240) as Developer of His Hermeneutics. Part 2: Ibn Barrajān's Views and Legacy”, Zeitschrift der Deutschen Morgenländischen Gesellschaft 163/2, 383-409.

Laroui, Abdallah (1977), The History of the Maghrib. An Interpretative Essay, trans. by Ralph Manheim, Princeton, N.J.: Princeton University Press.

López Lázaro, Fabio (2013), “The Rise and Global Significance of the First 'West': The Medieval Islamic Maghrib”, Journal of World History 24, 259-307.

Lucas, Scott C. (2008), "Where are the Legal Hadīth? A Study of the Muṣannaf of Ibn Abī Shayba", Islamic Law and Society 15, 283-314.

Maḥmūd al-Bațūsh, Āmina (2016), “Akhbār mamlakat Gharnāța fĩ al-mașādir al-mashriqiyya”, Jāmiat al-Quds al-maftūḥa li-l-abḥāth wa-l-dirāsāt 38, 241-278.

Marín, Manuela (1980), "Baqī b. Majlad y la introducción del estudio del 'ilm al-ḥadīt en al-Andalus”, Al-Qanțara 1, 165-208.

Marín, Manuela (1985), "Biografías de andalusíes en la obra de Ibn Mākūla”, in: Actas de las II Jornadas de Cultura Arabe e Islámica, Madrid: Instituto Hispano-Árabe de Cultura, 353364.

Marín, Manuela (1994), “El viaje a Oriente de Abū Marwān al-Bāŷī (m. 635/1237)”, in: Manuela Marín, ed., Estudios Onomástico-Biográficos de al-Andalus 6 (Homenaje a José M. $\stackrel{\text { Fór- }}{ }$ neas), Madrid: CSIC, 273-304.

Marín, Manuela (1995), “Des migrations forcées: les savants d'al-Andalus face à la conquête chrétienne", in: Mohammed Hammam, ed., La Méditerranée occidentale au Moyen Âge, Rabat, 43-59. 
Marín, Manuela (1998-1999), “Biographical Dictionaries and Social History of al-Andalus: Trade and Scholarship”, Scripta Mediterranea 19-20, 239-257.

Marín, Manuela (1999), “Historical images of al-Andalus and Andalusians”, in: Angelika Neuwirth, Birgit Embaló, Sebastian Günther and Maher Jarrar, eds., Myths, historical archetypes and symbolic figures in Arabic literature: towards a new hermeneutic approach (Proceedings of the International Symposium in Beirut, June 25th-June 30th, 1996), Stuttgart: Franz Steiner Verlag, 409-421.

Marín, Manuela (2001), “Signos visuales de la identidad andalusí”, in: Manuela Marín, ed., Tejer y vestir: de la antigüedad al islam, Madrid: CSIC, 137-180.

Marín, Manuela (2005), “Viajeros magrebíes en Egipto: una mirada conflictiva”, in: Juan Pedro Monferrer Sala and María Dolores Rodríguez Gómez, eds., Entre oriente y occidente: ciudades y viajeros en la Edad Media, Granada: Universidad de Granada, 215-230.

Martínez-Gros, Gabriel (1997), Identité andalouse, Paris: Sindbad-Actes Sud.

Melchert, Christopher (2012), "Centre and Periphery in the Transmission of Hadith, 8th-9th Centuries C.E.”, in: Giuseppe Contu, ed., Centre and Periphery within the Borders of Islam. Proceedings of the 23rd Congress of L'Union Européenne des Arabisants et Islamisants (Sassari, 28 September-1 October 2006), Leuven: Peeters, 53-60.

Molina, Luis (2020), “The integration of al-Andalus in Islamic historiography. The view from the Maghrib and the Mashriq", in: Maribel Fierro, ed., The Routledge Handbook of Muslim Iberia, Abingdon, Oxon - New York: Routledge, 572-585.

Monroe, James T. (1974), Hispano-Arabic Poetry. A Student Anthology, Berkeley - Los Angeles - London: University of California Press.

Moral, Celia del (2014), “Un monumento literario a la memoria de Ibn al-Jațīb: el Nafth al-țīb de al-Maqqarī”, in: M. ㅁ D. Rodríguez Gómez, A. Peláez Rovira and B. Boloix Gallardo, eds., Saber y poder en al-Andalus. Ibn al-Jațīb (siglo XIV), Córdoba: Ediciones El Almendro, 183202.

Mu'ammar, Nūrī (1988), al-Imām Abū 'Abd al-Raḥmān Baqī b. Makhlad shaykh al-ḥuffāẓ bi-lAndalus, Rabat: Mațābi' 'Ukāẓ.

Mu'ammar, Nūrī (1996), Mu'jam shuyūkh Abī 'Abd al-Raḥmān Baqī b. Makhlad al-Qurțubī alAndalusī (t. 276 h.), Rabat: Dār al-Ḥadīth al-Ḥasaniyya.

Al-Munajjid, Șalāḥ al-Dīn (1963), al-Mashriq fĩ naẓar al-maghāriba wa-l-andalusiyyīn fĩ alqurūn al-wusțā, Beirut: Dār al-Kitāb al-Jadīd.

Al-Musawi, Muhsin J. (2015), The Medieval Islamic Republic of Letters. Arabic Knowledge Construction, Notre Dame, Indiana: University of Notre Dame Press.

Al-Najmī, Khālid b. 'Alī (2015), Min al-Bilyār ilā Baghdād: al-Ḥumaydī al-Andalusī rasūl Ibn Ḥazm ilā al-Mashriq: ḥayātuhu wa-kitābuhu Jadhwat al-muqtabis, 2 vols., Riyadh: Maktabat wa-Dār Ibn Ḥazm.

Nasser, Shady (2013), “The Two-Rāwī Canon before and after ad-Dānī (d. 444/1052-3): The Role of Abū ț-Ṭayyib Ibn Ghalbūn (d. 389/998) and the Qayrawān/Andalus School in Creating the Two-Rāwī Canon”, Oriens 41, 41-75.

Özkan, Hakan (2018), "L'émancipation du zağal oriental de ses modèles andalous à l'ère mamelouke", Asiatische Studien - Études Asiatiques 72/3, 819-862.

Pellat, Charles (1954), “Ibn Ḥazm, bibliographe et apologiste de l’Espagne musulmane”, AlAndalus 19, 53-102.

Pellat, Ch., "Ibn Abī Shayba”, The Encyclopaedia of Islam, 2nd ed., Brill Online.

Pouzet, Louis (1975), “Maghrébins à Damas au VII' /XIII siècle”, Bulletin d'études orientales 28, 167-199. 
Raisuddin, A.N.M. (1988), "Baqī b. Makhlad al-Qurțubī (201-276/816-889) and His Contribution to the Study of hadith Literature in Muslim Spain”, Islamic Studies 27, 161-168.

Raisuddin, A.N.M. (1993), Spanish Contribution to the Study of Hadith Literature, Karachi: Royal Book Company.

Riedel, Dagmar (forthcoming), “The Diffusion of Qāḍi 'lyāḍ’s al-Shifā’ in Ottoman libraries”.

Romanov, Maxim (2017), “Algorithmic Analysis of Medieval Arabic Biographical Collections", Speculum 92, 226-246.

Rouighi, Ramzi (2010), “The Andalusi origins of the Berbers?”, Journal of Medieval Iberian Studies 2/1, 93-108.

Rouighi, Ramzi (2019), Inventing the Berbers. History and Ideology in the Maghrib, Philadelphia: University of Pennsylvania Press.

Sabra, Abdelhamid I. (1984), "The Andalusian Revolt against Ptolemaic Astronomy: Averroes and al-Bitrūjī”, in: Everett Mendelsohn, ed., Transformation and Tradition in the Sciences. Essays in Honor of I. Bernard Cohen, Cambridge: Cambridge University Press, 133-153.

Sadan, Joseph (2002), "Un intellectuel juif au confluent de deux cultures : Yehûda al-Harîzî et sa biographie arabe", in: Maribel Fierro, ed., Judíos y musulmanes en al-Andalus y el Magreb: contactos intelectuales, Madrid: Casa de Velázquez, 105-152.

Saleh, Walid A. (2011), "Marginalia and Peripheries: a Tunisian Historian and the History of Qur'anic Exegesis”, Numen 58, 284-313.

Sālim al-Nawāfa'a, Niḍāl (2008), al-Adab al-andalusĩ fí al-mawsū'āt al-adabiyya fí al-'așr almamlūkī, PhD dissertation, Jāmi'at Mut'a.

Schmidtke, Sabine (2012), “Ibn Ḥazm’s Sources on Ash'arism and Mu'tazilism”, in: Camilla Adang, Maribel Fierro and Sabine Schmidtke, eds., Ibn Hazm of Cordoba. The Life and Works of a Controversial Thinker, Leiden: Brill, 373-401.

Sciortino, Maria Grazia (2010), “The presence of Mašriqian 'ulamā’ at Aḥmad al-Manșūr's court according to the Mağribian tarāğim of the period”, Oriente Moderno 90/2, 427-434.

Soravia, Bruna (2019), "Li-kull dahr dawla wa-riğāl : temps, auteurs et autorité chez les théoriciens andalous de la kitāba, $\mathrm{v}^{\mathrm{e}} / \mathrm{Xl}^{\mathrm{e}}$ - $\mathrm{Vl}^{\mathrm{e}} / \mathrm{XII}^{\mathrm{e}}$ siècles", Arabica 66, 303-326.

Toral-Niehoff, Isabel (2015), “History in Adab Context: 'The Book on Caliphal Histories' by Ibn 'Abd Rabbihi (246/860-328/940)", Journal of Abbasid Studies 2, 61-85.

Usman, Muhammad Tukur (2009), "Maghreb Influence on the Arabic Literary Tradition of Northern Nigeria", The Maghreb review 34/2-3, 207-226.

Vázquez Hernández, Virginia (2018), “Local scholars in a global work: Andalusi biographical dictionaries in Ḥajjī Khalīfa's Kashf al-ẓunūn”, Anaquel de Estudios Arabes 29, 317-331.

Walker, P. E. (2014), "Fāṭimid Alexandria as an Entrepôt in the East-West Exchange of Islamic Scholarship", Al-Masāq 26/1, 36-48.

Wasserstrom, Steven M. (2000), "Jewish-Muslim Relations in the Context of Andalusian Emigration", in: Mark D. Meyerson and Edward D. English, eds., Christians, Muslims, and Jews in Medieval and Early Modern Spain. Interaction and Cultural Change, Notre Dame: University of Notre Dame Press, 69-87.

Weber, Elka (2000), “Construction of identity in twelfth-century Andalusia: the case of travel writing", The Journal of North African Studies 5/2,1-8.

Yukawa, Takeshi (1979), "The activities and influences of Maghribi and Andalusi 'ulamā' in Egypt-a study of the geographical mobility of the 'ulamā' in medieval Islam", Bulletin of the Society for Near Eastern Studies in Japan 22/2, 57-74 (in Japanese with English abstract). 
Zanón, Jesús (1997), "La actividad intelectual: las ramas del saber. Centros y métodos de conocimiento”, in: M. J. Viguera Molins, ed., Historia de España Menéndez Pidal VIII-2. El retroceso territorial de al-Andalus. Almorávides y Almohades, siglos XI al XIII, Madrid: EspasaCalpe, 549-586. 